\title{
MENINGKATKAN PROFESIONALISME GURU DALAM MELAKSANAKAN PEMBELAJARAN FISIKA MELALUI BIMBINGAN TEKNIK KERJA KELOMPOK
}

\author{
Penjelasan \\ Jurusan Pendidikan Fisika, Pascasarjana Universitas Negeri Medan
}

\begin{abstract}
Abstrak. Penelitian ini bertujuan untuk meningkatkan profesionalisme guru dalam melaksanakan pembelajaran Fisika melalui bimbingan teknik kerja kelompok di Sub Rayon 05 SMA Negeri 1 Percut Sei Tuan. Subjek penelitian ini adalah guru-guru Fisika SMA yang termasuk dalam Sub Rayon 05 SMA Negeri 1 Percut Sei Tuan yang berjumlah 15 orang. Metode penelitian yang diterapkan adalah Penelitian Tindakan Sekolah melalui dua siklus, dimana setiap siklus terdiri dari kegiatan perencanaan, pelaksanaan, pengamatan dan refleksi. Hasil analisis data menunjukkan bahwa (1) Melalui penerapan bimbingan teknik kerja kelompok terhadap guru-guru Fisika di Sub Rayon 05 SMA Negeri 1 Percut Sei Tuan, pengetahuan mereka tentang metode, strategi, model dan pendekatan pembelajaran yang termasuk dalam model pembelajaran Fisika mengalami peningkatan. (2) Ada peningkatan kemampuan guru-guru Fisika di Sub Rayon 05 SMA Negeri 1 Percut Sei Tuan dalam mengimplementasikan model pembelajaran dengan melaksanakan bimbingan teknik kerja kelompok. (3) Melalui penerapan bimbingan teknik kerja kelompok, terjadi peningkatan kemampuan guru-guru Fisika di Sub Rayon 05 SMA Negeri 1 Percut Sei Tuan dalam menyusun Rencana Pelaksanaan Pembelajaran sesuai dengan model atau strategi pembelajaran. (4) Ada peningkatan kemampuan guru-guru Fisika di Sub Rayon 05 SMA Negeri 1 Percut Sei Tuan dalam membuat instrumen penilaian.
\end{abstract}

Kata kunci: profesionalisme guru, pembelajaran fisika, bimbingan teknik, kerja kelompok

\section{IMPROVE TEACHER PROFESSIONALISM IN IMPLEMENTING LEARNING PHYSICS THROUGH TECHNICAL GUIDANCE GROUP WORK}

\author{
Penjelasan \\ Physics Education Program, Graduate State University of Medan
}

\begin{abstract}
The objective in this research is to improve the professionalism of teachers in implementing the guidance of physics learning through group work techniques in Sub Rayon 05 SMA Negeri 1 Percut Sei Tuan. The subjects were high school physics teachers are included in Sub Rayon 05 SMA Negeri 1 Percut Sei Tuan, amounting to 15 people. The research method applied is Action Research School through two cycles, with each cycle consisting of planning, implementation, observation and reflection. Results of data analysis showed that (1) through the application of technical guidance to the group work of teachers in the Physics Sub Rayon 05 SMA Negeri 1 Percut
\end{abstract}


Sei Tuan, their knowledge of the methods, strategies, models and learning approach that includes the model of physics learning experience improvement. (2) There is an increase in the ability of physics teachers in Sub Rayon 05 SMA Negeri 1 Percut Sei Tuan in implementing models learning to implement technical guidance group work. (3) Through the implementation of technical assistance work group, an increase in the ability of physics teachers in Sub Rayon 05 SMA Negeri 1 Percut Sei Tuan in preparing lesson plan in accordance with the model or learning strategies. (4) There is an increase in the ability of physics teachers in Sub Rayon 05 SMA Negeri 1 Percut Sei Tuan in making the assessment instrument.

\section{Keywords: professionalism of teachers, teaching physics, techniques guidance, group work}

\section{PENDAHULUAN}

Pengembangan profesi keguruan sebagaimana yang dimaksud dalam petunjuk teknis jabatan fungsional guru dan angka kreditnya adalah kegiatan guru dalam rangka pengamalan ilmu dan pengetahuan, teknologi dan keterampilan untuk peningkatan mutu baik bagi proses belajar mengajar dan profesionalisme tenaga kependidikan lainnya maupun dalam rangka menghasilkan sesuatu yang bermanfaat bagi pendidikan. Dalam hal ini, unsur pengembangan profesi sifatnya wajib bagi guru yang telah menduduki pangkat dan jabatan Guru Pembina, hal ini dikarenakan pangkat jabatan Guru Pembina diharapkan tumbuh daya analisis, kritis serta mampu memecahkan masalah dalam lingkup tugasnya.

Guru profesional harus memiliki kompetensi yang memenuhi ketentuan perundangundangan. Dalam Standar Kualifikasi dan Kompetensi Guru berdasarkan Permendiknas Nomor 16 tahun 2007 dinyatakan bahwa guru harus memiliki 4 kompetensi utama, yaitu kompetensi pedagogik, kepribadian, sosial, dan profesional yang terintegrasi dalam kinerja guru. Beberapa kompetensi inti guru mata pelajaran yang berhubungan langsung dengan pembelajaran di antaranya: (1) menguasai teori belajar dan prinsip-prinsip pembelajaran yang mendidik; (2) menyelenggarakan pembelajaran yang mendidik; (3) memanfaatkan teknologi informasi dan komunikasi untuk kepentingan pembelajaran.

Profesional menurut Korten \& Alfonso (1981) adalah kecocokan (fitness) antara kemampuan yang dimiliki oleh birokrasi (bureaucratic-competence) dengan kebutuhan tugas (task-requirement), merencanakan, mengkoordinasikan, dan melaksanakan fungsinya secara efisien, inovatif, lentur, dan mempunyai etos kerja tinggi. Pandangan lain seperti yang dikemukakan Siagian (2000) bahwa yang dimaksud dengan profesionalisme adalah keandalan dalam pelaksanaan tugas sehingga terlaksana dengan mutu tinggi, waktu yang tepat, cermat, dan dengan prosedur yang mudah dipahami dan diikuti oleh pelanggan.

Kusnandar (2007) mengemukakan bahwa profesionalisme adalah kondisi, arah, nilai, tujuan, dan kualitas suatu keahlian dan kewenangan yang berkaitan dengan mata pencaharian sesseorang. Sementara itu Danim (2002) mendefinisikan bahwa, profesionalisme adalah komitmen para anggota suatu profesi untuk meningkatkan kemampuan profesionalnya dan terus-menerus mengembangkan strategistrategi yang digunakannya dalam melakukan pekerjaan sesuai dengan profesinya itu. Sedangkan Poerwopoespito \& Utomo (2000) mengemukakan bahwa profesionalisme berarti faham yang menempatkan profesi sebagai titik perhatian utama dalam hidup seseorang. Orang yang menganut faham profesionalisme selalu 
menunjukkan sikap profesional dalam bekerja dan dalam keseharian hidupnya. Profesionalisme pada intinya adalah kompetensi untuk melaksanakan tugas dan fungsinya secara baik dan benar (MenPAN, 2002). Maksud dari profesional adalah kemampuan, keahlian atau keterampilan seseorang dalam bidang tertentu yang ditekuninya sedemikian rupa dalam kurun waktu tertentu yang relatif lama sehingga hasil kerjanya bernilai tinggi dan diakui serta diterima masyarakat (MenPAN, 2002).

Untuk menunjukkan bahwa guru adalah jabatan professional dapat diketahui dari perannya dalam melaksanakan kegiatan belajar mengajar. Kita ketahui bahwa proses belajar mengajar merupakan inti dari proses pendidikan formal di sekolah yang didalamnya terjadi interaksi antara komponen-komponen pembelajaran yang terdiri dari guru, materi pelajaran dan siswa. Interaksi ketiga komponen tersebut melibatkan sarana dan prasarana, seperti metode pembelajaran, media pembelajaran dan penataan lingkungan tempat belajar sehingga tercipta situasi pembelajaran yang memungkinkan tercapainya tujuan yang direncanakan. Dalam hal ini, guru memegang peranan sentral dalam proses pembelajaran.

Pada proses pembelajaran, awalnya guru harus berperan aktif, dimana guru memberikan pengetahuan yang dibutuhkan siswa dengan mengemukakan pendapat, bertanya, menjelaskan, memberikan contoh yang akan dipelajari siswa. Ada beberapa peran guru dalam melaksanakan proses pembelajaran, seperti yang dikemukakan Sanjaya (2008), yaitu (1) Guru sebagai sumber belajar, (2) Guru merencanakan pembelajaran, (3) Guru sebagai fasilitator, (4) Guru melaksanakan pembelajaran, (5) Guru sebagai pengelola, (6) Guru sebagai Motivator, (7) Guru sebagai demonstrator, (8) Guru mengevaluasi pembelajaran, (9) Guru sebagai pembimbing, (10) Guru memberikan umpan balik, (11) Guru sebagai evaluator.

Berdasarkan observasi awal, pada umumnya guru-guru, khususnya guru-guru Fisika yang bertugas di Sub Rayon 05 SMA Negeri 1 Percut Sei Tuan Kabupaten Deli Serdang belum melaksanakan berbagai inovasi pembelajaran. Sebanyak 15 orang guru Fisika yang akan menjadi subjek dalam penelitian ini, $80 \%$ tidak pernah berusaha untuk membuat perubahan proses pembelajaran sesuai dengan tuntutan kurikulum, yaitu menerapkan berbagai pendekatan, strategi, metode, dan teknik pembelajaran yang mendidik secara kreatif dalam pelajaran yang diampu. Dalam mengimplementasikan kompetensinya di lapangan, banyak tantangan yang perlu dihadapi para guru, terutama dengan beragamnya lapangan yang dihadapi dan berkembangnya ilmu dari masa ke masa. Untuk itu guru harus selalu memperbaharui pengetahuan dan kemampuannya agar dapat menjawab tantangan jaman. Sehubungan dengan peningkatan kinerja guru dalam pemenuhan kompetensi-kompetensi tersebut di atas, diperlukan pengetahuan mengenai inovasi pembelajaran. Apabila inovasi pembelajaran dilakukan guru dengan sungguh-sungguh dan benar, maka akan memberikan dampak positif terhadap peningkatan kualitas pembelajaran Fisika.

Berkenaan dengan implementasi Kurikulum Tingkat Satuan Pendidikan (KTSP), di mana tenaga pendidik diberi kewenangan penuh untuk melakukan perencanaan pembelajaran terhadap mata pelajaran yang diampunya sesuai dengan lingkungan dan kondisi peserta didik serta kondisi di mana sekolah berada. Selain Program Tahunan (Prota) dan Program Semester (Prosem), dimensi perencanaan proses pembelajaran Fisika yang harus memiliki nuansa inovasi. Perencanaan proses pembelajaran meliputi silabus dan rencana pelaksanaan pembelajaran (RPP) yang memuat identitas mata pelajaran, standar kompetensi (SK), kompetensi dasar (KD), indikator pencapaian kompetensi, tujuan pembelajaran, materi ajar, alokasi waktu, metode pembelajaran, kegiatan pembelajaran, penilaian hasil belajar, dan sumber belajar. Ini memberikan petunjuk kepada guru-guru, khususnya guru Fisika bahwa boleh membuat inovasi terhadap perencanaan proses pembelajaran tersebut sesuai dengan kondisi siswa. 
Berdasarkan pengalaman selama menjadi pengawas dalam memberikan supervisi di Musyawarah Guru Mata Pelajaran (MGMP), pada umumnya guru-guru Fisika di Sub Rayon 05 SMA Negeri 1 Percut Sei Tuan dan kepala sekolah tidak permah berusaha untuk memperbaiki proses pembelajaran yang dilaksanakannya dengan melaksanakan berbagai inovasi pembelajaran. Guru-guru Fisika ini 80\% sudah sertifikasi, tetapi tidak ada yang berupaya untuk memperbaiki proses pembelajaran. Dari hasil observasi awal selama enam bulan terakhir diketahui banyak hal yang menjadi penyebab kenapa guru-guru Fisika tersebut tidak membuat inovasi pembelajaran selama proses pembelajaran berlangsung. Kesulitan utama guru dalam merencanakan pembelajaran adalah:

1) Kurangnya pengetahuan guru-guru Fisika tentang berbagai metode, strategi, model dan pendekatan pembelajaran sebanyak 13 orang $(86,67 \%)$.

2) Lemahnya kemampuan guru-guru Fisika dalam mengimplementasikan model atau strategi pembelajaran inovatif sebanyak 14 orang $(93,33 \%)$.

3) Menyusun Rencana Pelaksanaan Pembelajaran sesuai dengan model atau strategi pembelajaran sebanyak 8 orang $(53,33 \%)$.

4) Merancang media pembelajaran Fisika yang tidak tersedia di sekolah sebanyak 9 orang $(60,00 \%)$.

5) Membuat instrumen penilaian, seperti Lembar Observasi Siswa, Lembar Observasi Guru, Lembar Kerja Siswa sebanyak 12 orang $(80,00 \%)$.

Berdasarkan latar belakang masalah, penelitian ini difokuskan pada (1) meningkatkan pengetahuan guru-guru Fisika tentang metode, strategi, model dan pendekatan pembelajaran, (2) meningkatkan kemampuan guru-guru Fisika dalam mengimplementasikan model pembelajaran, (3) meningkatkan kemampuan guru-guru Fisika dalam menyusun Rencana Pelaksanaan Pembelajaran sesuai dengan model pembelajaran yang digunakan, (4) meningkatkan kemampuan guru-guru Fisika dalam membuat instrumen penilaian pembelajaran.

Ke-empat fokus dalam penelitian ini akan ditingkatkan melalui penerapan bimbingan teknik kerja kelompok. Menurut Fikri (1994) melalui ulasan terhadap pendapat beberapa para ahli menyatakan bahwa bimbingan teknis adalah suatu proses kegiatan berlanjut yang memberikan tuntunan, arahan dan memanfaatkan kekuatan yang ada pada seseorang sehingga yang besangkutan menjadi mahir dan terampil untuk mengerjakan sesuatu menjadi produktif. Bimbingan teknis merupakan sarana manajemen untuk diartikan sebagai proses berlanjut yang mempengaruhi perilaku. Dengan bertatap muka pembimbing dengan yang dibimbing dapat bekerjasama untuk mencapai pengetahuan pekerjaan yang lebih tinggi, peningkatan keterampilan dalam melaksanakan pekerjaannya.

\section{METODE PENELITIAN}

Penelitian ini dilaksanakan di Subrayon 05 SMA Negeri 1 Percut Sei Tuan Kabupaten Deli Serdang. Lokasi ini ditetapkan sebagai lokasi penelitian karena Peneliti bertugas sebagai Pengawas Sekolah di Subrayon 05 SMA Negeri 1 Percut Sei Tuan, sehingga dapat memperlancar dalam pelaksanaannya. Waktu pelaksanaan penelitian ini dijadwalkan mulai Januari 2013 sampai Maret 2013, tepatnya di semester genap Tahun Pelajaran 2012/2013.

Subjek penelitian yang akan diberi tindakan adalah guru-guru SMA se-Subrayon 05 SMA Negeri 1 Percut Sei Tuan Kabupaten Deli Serdang. Guru-guru yang menjadi subjek penelitian berjumlah 15 orang terdiri dari 8 orang guru laki-laki dan 7 orang guru perempuan. Metode penelitian yang diterapkan dalam peneltiian ini adalah Penelitian Tindakan Sekolah (PTS) melalui dua siklus tindakan. Setiap siklus terdiri dari kegiatan perencanaan tindakan, pelaksanaan tindakan, pengamatan dan evaluasi/refleksi. 


\section{HASIL PENELITIAN DAN PEMBAHASAN Deskripsi Awal}

Berdasarkan hasil observasi awal yang dilakukan pada pelaksanaan Musyawarah Guru Mata Pelajaran (MGMP) guru-guru Fisika di Sub Rayon 05 SMA Negeri 1 Percut Sei Tuan Tahun Pelajaran 2012/2013 diketahui bahwa pada umumnya guru-guru Fisika dan kepala sekolah tidak pernah berusaha untuk memperbaiki proses pembelajaran yang dilaksanakannya melalui pelaksanaan berbagai pembelajaran. Tercatat pula bahwa guru-guru Fisika ini $80 \%$ sudah sertifikasi, tetapi tidak ada yang berupaya untuk memperbaiki proses pembelajaran. Observasi awal selama enam bulan terakhir ini diketahui banyak hal yang menjadi penyebab kenapa guru-guru Fisika tersebut tidak membuat inovasi pembelajaran selama proses pembelajaran berlangsung. Kesulitan utama guru dalam merencanakan pembelajaran adalah (1) guru-guru Fisika kurang memahami berbagai metode, strategi, model dan pendekatan pembelajaran, sebanyak 13 orang $(86,67 \%)$, (2) kemampuan guru-guru Fisika dalam mengimplementasikan model atau strategi pembelajaran inovatif sangat lemah, sebanyak 14 orang (93,33\%), (3) guru-guru Fisika kurang mampu dalam menyusun Rencana Pelaksanaan Pembelajaran sesuai dengan model atau strategi pembelajaran yang akan diterapkannya sebanyak 8 orang $(53,33 \%)$, (4) guru-guru Fisika mengalami kesulitan dalam merancang media pembelajaran Fisika yang tidak tersedia di sekolah sebanyak 9 orang $(60,00 \%)$, (5) guru-guru Fisika tidak mampu membuat instrumen penilaian, seperti Lembar Observasi Siswa, Lembar Observasi Guru, Lembar Kerja Siswa sebanyak 12 orang $(80,00 \%)$. Atas dasar informasi awal ini, peneliti akan melakukan kegiatan bimbingan teknik kerja kelompok untuk meningkatkan profesionalisme guru-guru dalam melaksanakan pembelajaran Fisika.

\section{Hasil Analisis Data \\ Pengetahuan Guru-guru Fisika Tentang Menerapkan Metode, Strategi, Model dan Pendekatan Pembelajaran}

Dalam upaya meningkatkan pengetahuan guru-guru Fisika tentang metode, strategi, model dan pendekatan pembelajaran yang termasuk dalam metode atau model inovasi pembelajaran Fisika, peneliti memberikan bimbingan melalui kegiatan bimbingan teknik kerja kelompok. Dalam pelaksanaannya, guruguru dibagi menjadi 5 kelompok, setiap kelompok beranggotakan 3 orang. Meskipun mereka bekerja dalam kelompok, tetapi pengamatan dilakukan secara individu. Tujuannya adalah supaya dalam melakukan kerja kelompok, mereka akan lebih sungguhsungguh dan bertanggung jawab.

Observasi terhadap pengetahuan dan pemahaman guru-guru tentang metode atau model pembelajaran dilakukan untuk 10 aspek pengamatan, yaitu

1. Menerapkan metode pembelajaran dalam melaksanakan proses pembelajaran.

2. Menerapkan model pembelajaran dalam melaksanakan kegiatan belajar mengajar.

3. Menerapkan strategi pembelajaran dalam proses pembelajaran.

4. Menggunakan model pembelajaran yang berfokus pada aktivitas siswa.

5. Menerapkan metode dan strategi pembelajaran dalam mensukseskan model pembelajaran.

6. Menerapkan teori-teori pembelajaran yang sesuai dengan langkah-langkahnya.

7. Menggunakan teori pembelajaran untuk memahami dalam penerapannya.

8. Guru menjalankan tugas mengajar sesuai dengan tupoksinya.

9. Guru mendiskusikan kepada sesama guru tentang kegiatan pembelajaran yang sudah dilaksanakan.

10. Guru mata pelajaran menggunakan model pembelajaran yang bervariasi dan Paikem.

Sedangkan skor yang diberikan berdasarkan skala Likert, yaitu Skor 1: tidak pernah, Skor 2: kadang-kadang, Skor 3: sering, dan Skor 4: selalu. Hasil observasi menunjukkan bahwa Sebagai kesimpulan sementara dapat dikatakan bahwa pada umumnya guru-guru Fisika tergolong sering dalam menerapkan 
aspek pengamatan yang menjadi fokus perhatian dalam melaksanakan proses pembelajaran di kelas. Pada siklus pertama ini, dapat dikatakan bahwa guru-guru Fisika sudah mampu menerapkan beberapa hal yang diperlukan dalam proses pembelajaran. Sebagai rekomendasi perbaikan untuk siklus berikutnya, peneliti harus lebih fokus dan intensif dalam memberi bimbingan dalam kelompok, khususnya pertanggung jawaban individu dalam setiap kelompok. Sedangkan pada siklus kedua dapat dikatakan bahwa guru-guru Fisika sudah mampu menerapkan beberapa aspek dalam metode, model, strategi dan pendekatan yang diperlukan dalam proses pembelajaran.

Kemampuan guru-guru dalam mengimplementasikan model atau strategi pembelajaran

Kemampuan guru-guru Fisika dalam mengimplementasikan model atau strategi pembelajaran difokuskan pada 8 aspek pengamatan, yaitu

1. Kemampuan Membuka Pelajaran.

2. Sikap Guru dalam Proses Pembelajaran

3. Penguasaan Bahan Belajar (Materi Pelajaran)

4. Kegiatan Belajar Mengajar (Proses

Pembelajaran)

5. Kemampuan Menggunakan Media

Pembelajaran

6. Evaluasi Pembelajaran

7. Kemampuan Menutup Kegiatan

Pembelajaran

8. Tindak Lanjut/Follow up

Kriteria penilaian yang diberikan untuk aspek-aspek ini adalah nilai 4 jika semua deskriptor tampak (sangat baik), nilai 3 jika hanya 3 deskriptor yang tampak (baik), nilai 2 jika hanya 2 deskriptor yang tampak (cukup), nilai 1 jika hanya 1 deskriptor yang tampak (kurang), nilai 0 jika tidak ada deskriptor yang tampak (sangat kurang). Hasil analisis menunjukkan bahwa hanya pada aspek pengamatan 3 guru-guru Fisika memperoleh nilai rata-rata 2 , sedangkan aspek pengamatan 1, 2, 4, 5, 6, 7 dan 8 memperoleh nilai rata-rata 3. Ini berarti, secara klasikal guru-guru Fisika sudah baik kemampuannya dalam mengimple- mentasikan model atau strategi pembelajaran yang inovatif. Sedangkan pada siklus kedua secara klasikal guru-guru Fisika juga sudah baik kemampuannya dalam menginplementasikan model atau strategi pembelajaran yang inovatif.

\section{Kemampuan guru-guru Fisika Dalam Menyusun Rencana Pelaksanaan Pembela- jaran Sesuai Dengan Model atau Strategi Pembelajaran}

Pada aspek pengamatan terhadap kemampuan guru-guru Fisika dalam menyusun Rencana Pelaksanaan Pembelajaran sesuai dengan model pembelajaran difokuskan pada 4 aspek pengamatan, yaitu (1) Tujuan Pembelajaran, (2) Bahan Belajar/Materi Pelajaran, (3) Strategi/Metode Pembelajaran, (4) Media Pembelajaran, (5) Evaluasi.

Kriteria Penilaiannya adalah nilai 4 jika semua deskriptor tampak (sangat baik), nilai 3 jika hanya 3 deskriptor yang tampak (baik), nilai 2 jika hanya 2 deskriptor yang tampak (cukup), nilai 1 jika hanya 1 deskriptor yang tampak (kurang), nilai 0 jika tidak ada deskriptor yang tampak (sangat kurang). Hasil analisis data menunjukkan bahwa secara klasikal aspek pengamatan 3 diperoleh nilai rata-rata 2, ini berarti guru-guru Fisika memiliki kemampuan cukup merancang strategi atau metode pembelajaran dalam menyusun Rencana Pelaksanaan Pembelajaran. Sedangkan untuk aspek pengamatan1, 2, 4, dan 5 diperoleh nilai rata-rata 3, ini berarti guru-guru Fisika memiliki kemampuan baik dalam merumuskan tujuan pembelajaran, menyusun dan mempersiapkan materi pelajaran, menyusun dan menyiapkan media pembelajaran dan melaksanakan evaluasi pembelajaran, dalam menyusun Rencana Pelaksanaan Pembelajaran. Sebagai tindak lanjut dari kegiatan pembimbingan ini, peneliti sebaiknya lebih mengarahkan guruguru Fisika peserta bimbingan supaya mengikuti pedoman yang telah diberikan dan sesuai dengan lembar pengamatan. Sedangkan pada siklus kedua guru-guru Fisika memiliki kemampuan baik dalam merumuskan tujuan 
pembelajaran, menyusun dan mempersiapkan materi pelajaran, menyusun dan menyiapkan media pembelajaran dan melaksanakan evaluasi pembelajaran, dalam menyusun Rencana Pelaksanaan Pembelajaran.

\section{Kemampuan guru-guru Fisika dalam membuat instrumen penilaian}

Pada aspek pengamatan kemampuan guru-guru Fisika dalam membuat instrument penilaian difokuskan pada 5 aspek pengamatan, yaitu (1) Belajar Tuntas, (2) Penilaian Otentik, (3) Penilaian Berkesinambungan, (4) Penilaian Berdasarkan Acuan Kriteria/Patokan, (5) Penilaian Menggunakan Berbagai Cara dan Alat Penilaian. Kriteria Penilaian: Nilai 4: Sangat baik, Nilai 3: Baik, Nilai 2: Cukup, Nilai 1: Kurang. Hasil analisis data pada siklus I menunjukkan bahwa data kemampuan guruguru Fisika dalam membuat instrumen penilaian diperoleh nilai rata-rata 3 . Ini berarti, secara klasikal kemampuan guru-guru Fisika di Sub Rayon SMA Negeri 1 Percut Sei Tuan memiliki kemampuan yang baik dalam menyusun instrument penilaian. Meskipun demikian, ada beberapa aspek penilaian yang perlu mendapat perhatian khusus pada aspek penilaian belajar tuntas dan penilaian otentik. Sedangkan pada siklus kedua, secara klasikal kemampuan guru-guru Fisika memiliki kemampuan yang sangat baik dalam menyusun instrument penilaian.

\section{Simpulan}

Berdasarkan hasil analisis data pada siklus pertama dan siklus kedua dapat ditarik kesimpulan:

1. Melalui penerapan bimbingan teknik kerja kelompok terhadap guru-guru Fisika di Sub Rayon 05 SMA Negeri 1 Percut Sei Tuan, maka pengetahuan mereka tentang metode, strategi, model dan pendekatan pembelajaran yang termasuk dalam metode atau model inovasi pembelajaran Fisika mengalami peningkatan. Ini dibuktikan dengan seringnya mereka menerapkan metode atau model pembelajaran dalam melaksanakan proses pembelajaran, sehingga menjadi terbiasa dalam menerapkan metode atau model pembelajaran.

2. Ada peningkatan kemampuan guru-guru Fisika di Sub Rayon 05 SMA Negeri 1 Percut Sei Tuan dalam mengimplementasikan model atau strategi pembelajaran inovatif dengan melaksanakan bimbingan teknik kerja kelompok. Ini terbukti dari hasil pengamatan yang menunjukkan bahwa pada siklus pertama kemampuan guru-guru masih dalam kategori baik demikian juga pada siklus kedua, hanya saja pada siklus kedua aktivitas kelompok guru-guru cukup dinamis, sehingga semua peserta menjadi terbiasa dalam menerapkan metode atau model pembelajaran yang ditetapkan.

3. Melalui penerapan bimbingan teknik kerja kelompok, terjadi peningkatan kemampuan guru-guru Fisika di Sub Rayon 05 SMA Negeri 1 Percut Sei Tuan dalam menyusun Rencana Pelaksanaan Pembelajaran sesuai dengan model atau strategi pembelajaran. Pada siklus pertama, kemampuan guru-guru dalam menyusun Rencana Pelaksanaan Pembelajaran termasuk dalam kategori baik meskipun dalam kelompok atau hasil kerja kelompok, demikian juga pada siklus kedua kategori baik, akan tetapi pada siklus kedua setiap guru sudah mampu dalam menyusun rencana pelaksanaan pembelajaran.

4. Ada peningkatan kemampuan guru-guru Fisika di Sub Rayon 05 SMA Negeri 1 Percut Sei Tuan dalam membuat instrumen penilaian. Pada siklus pertama data kemampuan guru-guru Fisika di Sub Rayon 05 SMA Negeri 1 Percut Sei Tuan dalam membuat instrumen penilaian memiliki kemampuan yang baik. Meskipun ada beberapa aspek penilaian yang perlu mendapat perhatian khusus. Sedangkan pada siklus kedua, data kemampuan guruguru Fisika di Sub Rayon 05 SMA Negeri 1 Percut Sei Tuan dalam membuat instrumen penilaian secara klasikal memiliki kemampuan yang sangat baik. 


\section{DAFTAR PUSTAKA}

Badan Standar Nasional Pendidikan. 2007. Panduan Penilaian Kelompok Mata Pelajaran Ilmu Pengetahuan dan Teknologi. Jakarta: Departemen Pendidikan Nasional.

Danim, S. 2002. Inovasi Pendidikan dalam Upaya Peningkatan Profesionalisme Tenaga Kependidikan. Bandung: CV Pustaka Setia.

Korten, F. 1985. Community Participation a Management Perspective on Obstacles Anoption Bureaucracy and The Poor: Closing The Gap. (David Korten and Flipo B Alfonso eds). The Asian Institute of Management, Manila, 2 ad Printing.
Kusnandar. 2007. Guru Profesional. Jakarta: PT. RajaGrafindo.

Peraturan Menteri Pendayagunaan Aparatur Negara dan Reformasi Birokrasi Nomor 16 Tahun 2009 tentang Jabatan Fungsional guru angka kreditnya.

Poerwopoespito, O.S., dan Utomo, T. 2000. Mengatasi Krisis Manusia Di Perusahaan; Solusi Melalui Pengembangan Sikap Mental. Jakarta: PT. Gramedia Widiasarana Indonesia

Sanjaya, W. 2008. Strategi Pembelajaran Berorientasi Standar Proses Pendidikan. Jakarta: Penerbit Kencana.

Siagian, S.P. 2000. Manajemen sumber daya manusia. Jakarta: Bumi Aksara. 